\title{
Physico-Chemical and Optical Examination of Water Stored in Copper Vessels
}

\author{
Naidu Dhanpal Jayram, K. Viswanathan, Vinothkumar A, Mugeshkumar S, Vanitha V
}

\begin{abstract}
Storage of water in copper vessels is traditionally followed in past and many reports have been published about the antibacterial growth in copper vessel. It is essential to determine the water purity for drinking purposes in daily life through low cost approach. In the present work an attempt has been made to investigate the effect of storage of different drinking water in copper vessel for two week. The corresponding values of $\mathrm{pH}$ and TDS meter for different waters were recorded and analyzed. The optical properties such as $U V$-Vis and Raman studies along with physio-chemical parameters like $\mathrm{pH}$ and TDS were analyzed for 3weeks against different water sources kept in copper vessel. The Raman spectra provide information for different water sources. Similarly the UV-Vis spectroscopy provide the peak variation for different waters, however the effect of days and copper concentration analysis are in investigation. The Results obtained in this study reveals that water stored in copper vessel reduces the TDS level of bore water Tirunelveli and maintains its $\mathrm{pH}$ at 8.0 after 2 weeks. The bore water in Krishnan kovil (virudhunagar district) shows no variation in TDS after 1 week, but in $2^{\text {nd }}$ week there is sudden decrease in TDS from 1050 to $944 \mathrm{ppm}$ and $\mathrm{pH}$ level decreases to 8.3 showing alkaline nature. Throughout the experiment we have noticed that the colour of copper vessel changes in case of bore water. For variation in studies we have also studied the pH and TDS of Drinking water at Kalasalingam Academy of Research and Education. There is no change in colour of copper vessel and TDS and $\mathrm{pH}$ remains same up to one week, but in second week TDS increases to 100ppm while the pH remain constant at 7.4. These studies will help future researcher for designing of copper vessels and will help them to analyze the Physio-chemical studies of water. Moreover the chemical mechanism and reaction between copper vessel and leaching out of copper into water data base will be generated in future based on $U V$ and Raman studies.
\end{abstract}

Keywords :copper vessels, $\mathrm{pH}, \mathrm{TDS}$, Bore water, Drinking water.

\section{INTRODUCTION}

The continued rapid growth in human population demands for water resources in large quantity. Worldwide, more than

Revised Manuscript Received on December 09, 2019.

* Correspondence Author

Naidu Dhanpal Jayram *, Department of Physics , Kalasalingam Academy of Research and Education, Krishnankoil-626 126, Tamil Nadu, India Email : dhanpal@klu.ac.in

K. Viswanathan, Department of Physics, Kalasalingam Academy of Research and Education, Krishnankoil-626 126, Tamil Nadu, India Email : kvnooty@gmail.com

Vinothkumar A, Department of Physics, Kalasalingam Academy of Research and Education, Krishnankoil-626 126,Tamil Nadu, India Email : asvinothkumar0512@gmail.com

Mugeshkumar S, Department of Physics, Kalasalingam Academy of Research and Education, Krishnankoil-626 126,Tamil Nadu, India Email : mugeshkumar1912@gmail.com

Vanitha.V, Department of Physics, Kalasalingam Academy of Research and Education, Krishnankoil-626 126, Tamil Nadu, India Email : vanithakutty98@gmail.com one million deaths occur due to water-borne diarrheal diseases [1-2].Human health suffers due to contamination of drinking water. An approximation of more than 800 million people is not accessed to pure water source. In India, there the water supply through municipality from pipe linesare need to cleaned in rural and urban areas, resulting in a need to store water for drinking, food preparation and bathing purposes $[3,4]$. Drinking water at time of storage has to be checked properly and it's proper handling to be maintained for infected or bacteria free water. Traditionally, vessels made up of copper and its alloys and earthenware pots have been used in India for storing drinking water. Still the scientific community hasn't found much uses for copper but the ancient people has used for copper for many eating and drinking. According to ayurveda, less amount of copper can cause gastric problems and other diseases. WHO has recommended few limits for the intake of copper. WHO limits of $2000 \mathrm{ppb}$ (WHO, 2008) and BIS limits of 1500 ppb (BIS, 2009). Guideline value permits consumption of 2- 3 litres of water per day, use of a nutritional supplement. So drinking water in copper vessels for longer time won't effect on our health. Moreover the present study confirms that the copper doesn't leach out from the vessels

Many articles has reported that $50-70 \%$ bacteria like, Escherichia coli, Staphylococcus aureu fungi such as Candida albicans, viruses such as influenza viruses will be killed when kept in copper vessels for 16 to 20 hours[5-7]. The present study proposed to resolve the effect of different water storage in copper vessel for a 2 week. The corresponding values of $\mathrm{pH}$ and TDS meter for different waters were recorded and analyzed. As this work is in initial stage the UV-Vis and Raman studies will be extended for further investigation. Also the leaching of copper from vessel to water is to be determined.

\section{EXPERIMENTAL PROCEDURE}

\section{A. Copper vessel}

Copper glasses were purchased through local shop and $\mathrm{pH}$ and TDS meter were purchased online. For the study, 3 drinking sample were collected among which 2 were bore water from different districts of Tamil nadu and remaining one was regular drinking water of our university.

\section{B. Observation Table}

Tds and $\mathrm{pH}$ 
Table 1. TDS and $\mathrm{pH}$ readings

\begin{tabular}{|c|c|c|c|}
\hline \multirow[b]{2}{*}{$\begin{array}{c}\text { Storage of } \\
\text { water in } \\
\text { Days }\end{array}$} & \multicolumn{3}{|c|}{ TDS and pH reading } \\
\hline & $\begin{array}{c}\text { Bore well } \\
\text { Krishnan } \\
\text { kovil }\end{array}$ & $\begin{array}{r}\text { Bore well } 2 \\
\text { Tirunelveli }\end{array}$ & $\begin{array}{c}\text { Drinking water } \\
\text { Kalasalingam } \\
\text { University }\end{array}$ \\
\hline Day & $\mathrm{pH} \quad \mathrm{TDS}$ & $\mathrm{pH}$ TDS & $\mathrm{pH}$ TDS \\
\hline $1^{\mathrm{st}}$ & 8.41160 & $7.7 \quad 894$ & $7.5 \quad 30$ \\
\hline $2^{\text {nd }}$ & $\begin{array}{ll}8.2 & 1420\end{array}$ & 8.2900 & $8.0 \quad 31$ \\
\hline $3^{\text {rd }}$ & $8.4 \quad 1220$ & 8.1820 & $7.4 \quad 40$ \\
\hline $4^{\text {th }}$ & $8.0 \quad 1150$ & 8.0796 & $7.0 \quad 35$ \\
\hline $5^{\text {th }}$ & $7.9 \quad 1040$ & $8.0 \quad 740$ & $7.0 \quad 36$ \\
\hline $6^{\text {th }}$ & $8.1 \quad 1040$ & $8.0 \quad 721$ & $7.0 \quad 40$ \\
\hline $7^{\text {th }}$ & $8.1 \quad 1040$ & $8.0 \quad 722$ & $7.0 \quad 42$ \\
\hline $8^{\text {th }}$ & $\begin{array}{ll}8.3 & 1040\end{array}$ & $8.0 \quad 720$ & 7.148 \\
\hline $9^{\text {th }}$ & $8.3 \quad 1050$ & $8.0 \quad 717$ & $7.3 \quad 52$ \\
\hline $10^{\text {th }}$ & $8.5 \quad 1050$ & $8.1 \quad 715$ & $7.8 \quad 54$ \\
\hline $11^{\text {th }}$ & $8.5 \quad 1100$ & $8.1 \quad 714$ & $7.5 \quad 56$ \\
\hline $12^{\text {th }}$ & $8.1 \quad 1090$ & $8.0 \quad 712$ & $7.5 \quad 64$ \\
\hline $13^{\text {th }}$ & $8.4 \quad 1050$ & $7.8 \quad 696$ & $7.4 \quad 73$ \\
\hline $14^{\text {th }}$ & $8.2 \quad 996$ & $8.0 \quad 689$ & $7.4 \quad 86$ \\
\hline $15^{\text {th }}$ & $8.3 \quad 944$ & $8.0 \quad 680$ & $7.4 \quad 100$ \\
\hline
\end{tabular}

\section{RESULTS AND DISCUSSIONS}

Water with $\mathrm{pH}$ value more than 9 or less than 4.5 become unsuitable for most life forms and also for other uses. The desirable $\mathrm{pH}$ range for drinking water is $6.5-8.0 \mathrm{pH}$. In our experiments stored water ranges in between 7.0 to 8.4 as shown in figure 3.1. High $\mathrm{pH}$ is observed for bore well water Krishnankovil, while the $\mathrm{pH}$ for drinking water in our university shows low $\mathrm{pH}$ value of 7.0- 7.4. Copper has greater efficiency towards the $\mathrm{pH}$ water level and sometimes it makes water more alkaline when its $\mathrm{pH}$ is low. But in our experiment the drinking water available in university doesn't showed any variation in $\mathrm{pH}$ but the $\mathrm{pH}$ of bore water krishnankovil drastically decreases from 8.5 to 8.0 , similarly for bore water Tirunelveli also, $\mathrm{pH}$ decreases initially but later it maintains at $\mathrm{pH}$ 8.0. This can be due to ability of absorption of minerals through copper vessels [8-12]

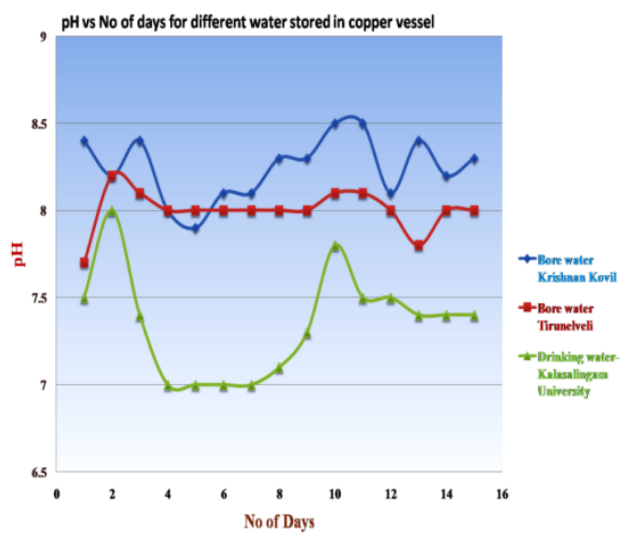

Fig. 1. Different water $\mathrm{pH}$ levels against the no of days in C. TDS copper vessel

TDS is an important indicator of overall water quality. TDS helps in understanding the level of turbidity and hardness of water It is a measure of inorganic and organic materials dissolved in water. High TDS concentration may cause a bad odour or taste to drinking water, as well as cause scaling of pipes and corrosion. Waters can be classified based on the concentrations of TDS [13-15] as given below.

Up to $450 \mathrm{mg} / \mathrm{L}-$ Desirable for drinking

Up to $980 \mathrm{mg} / \mathrm{L}-$ Permissible for drinking

Up to $2000 \mathrm{mg} / \mathrm{L}-$ Useful for irrigation

Up to3000mg/L-Not useful for drinking and irrigation.

In the present work the initial TDS of bore water tirunelveli was $894 \mathrm{ppm}$ and keeping in copper for more than 2 weeks, it drastically changes to $680 \mathrm{ppm}$, while Bore well water Krishnan kovil is found to be $1050 \mathrm{ppm}$ at initial days and remains constant even after one week. However at the end of $2^{\text {nd }}$ week it also drastically decreases to 9Similarly in case of university drinking water the TDS shows constant reading value of $944 \mathrm{ppm}$. The solvents in water could be absorbed by the copper vessels and the alkalinity of water changes to 8.0.

TDS Vs No of days for different stored water in copper vessel

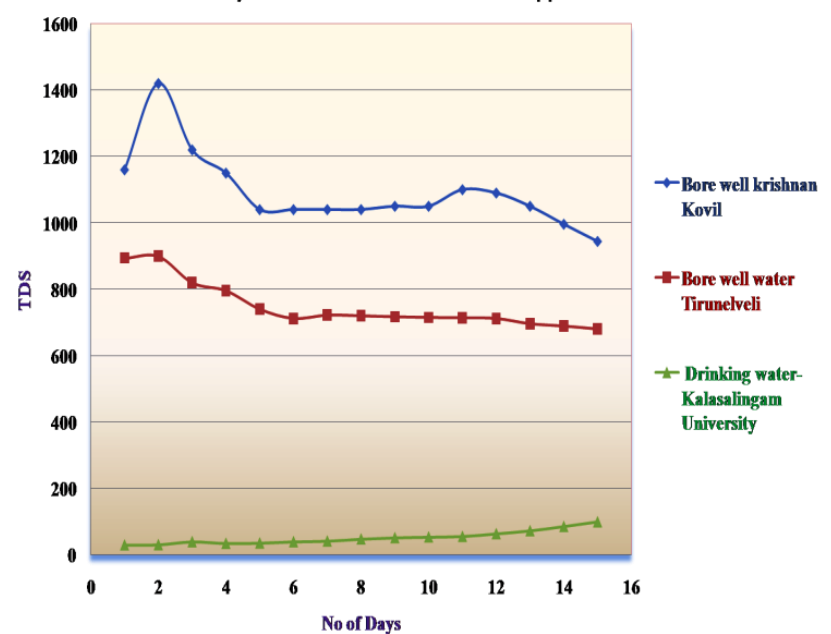

Fig. 2.Total dissolved salts in copper vessel for different waters

\section{COLOR CHANGE IN COPPER}

The ability of absorption of minerals through copper vessels can be absorbed in our experiment as shown in figure 3 . Copper has greater efficiency towards the $\mathrm{pH}$ water level and sometimes it makes water more alkaline when its $\mathrm{pH}$ is low. In our experiment the drinking water available in university doesn't showed any variation in $\mathrm{pH}$ and color of the copper vessel doesn't change from as purchased to till $16^{\text {th }}$ day of experiment. In the case of Bore water- Tirunelveli the color of the vessels changes to pale blue after $16^{\text {th }}$ day and this could we can also absorb in TDS reading. As discussed in the above figure 3.2, we have noticed down the drastic change in TDS from 900 to $689 \mathrm{ppm}$. While in the case of Bore waterKrishnan kovil the ppm level was above 1050 , but after $15^{\text {th }}$ day we found it decreases drastically and reached $944 \mathrm{ppm}$ 


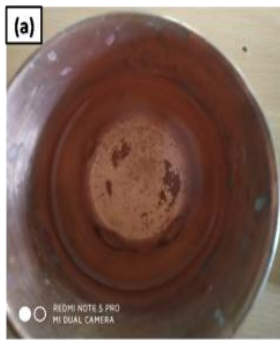

Bore water Krishnan Kovil

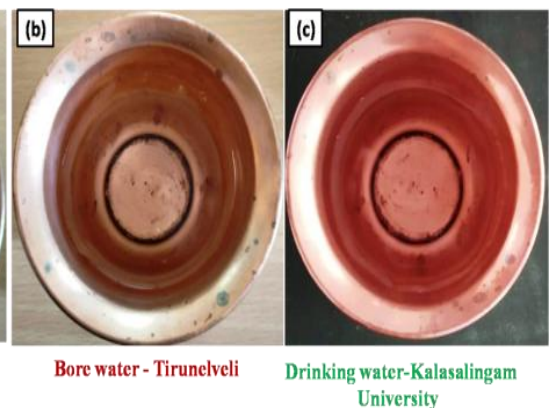

University
Fig. 3.Colour change of copper vessels

A. Uv visible Analysis
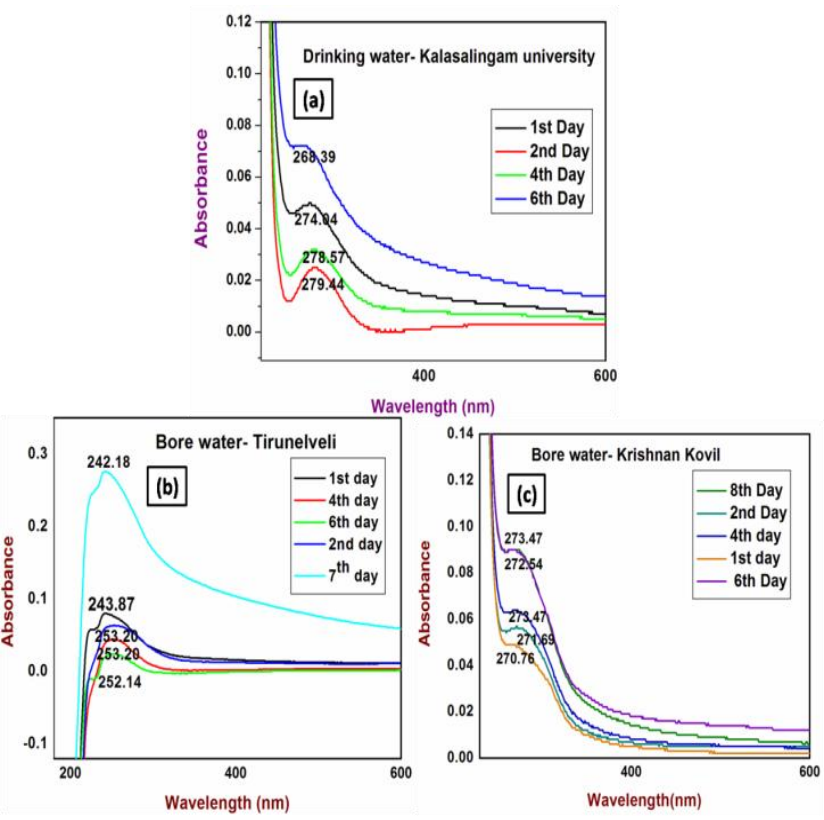

Fig. 4. UV-vis analysis of (a) Drinking water (b) Bore water Tirunelveli (c) Bore water Krishnan Kovil

\section{UV visible}

UV-vis analysis has been carried out to discuss the optical properties of bore water Tirunelveli, krishnankovil and kalsalingam university drinking water stored in copper vessel. Stored drinking water was subjected to UV-Visible spectroscopy analysis for consecutive even day's analysis. The reduction of $\mathrm{Cu}$ (II) to $\mathrm{CuO}$ particles was confirmed by the copper oxide peak at which correspond to absorption peaks at 279.44 and $268.39 \mathrm{~nm}$ respectively which are shown in Fig.4.

Similarly in case of Bore well water tirunelveli the peak shifted from 242.17 to 254.14. CuO particles exhibit Plasmon resonances, which are mostly sharp and well separated from inter band transitions. The red shift and the broadening of the band for drinking water Kalasalingam show larger particles. This is due to the dipole-dipole interaction among Copper particles coated on vessels and also electromagnetic coupling which enhances the polarizability of the electron cloud, resulting in red shift [16-18]. The absorbance spectra of bore water at $270 \mathrm{~nm}$ represent the specific peak corresponding to $\mathrm{Cu}-\mathrm{O}-\mathrm{Cu}$ bond which confirms the presence of copper particles.

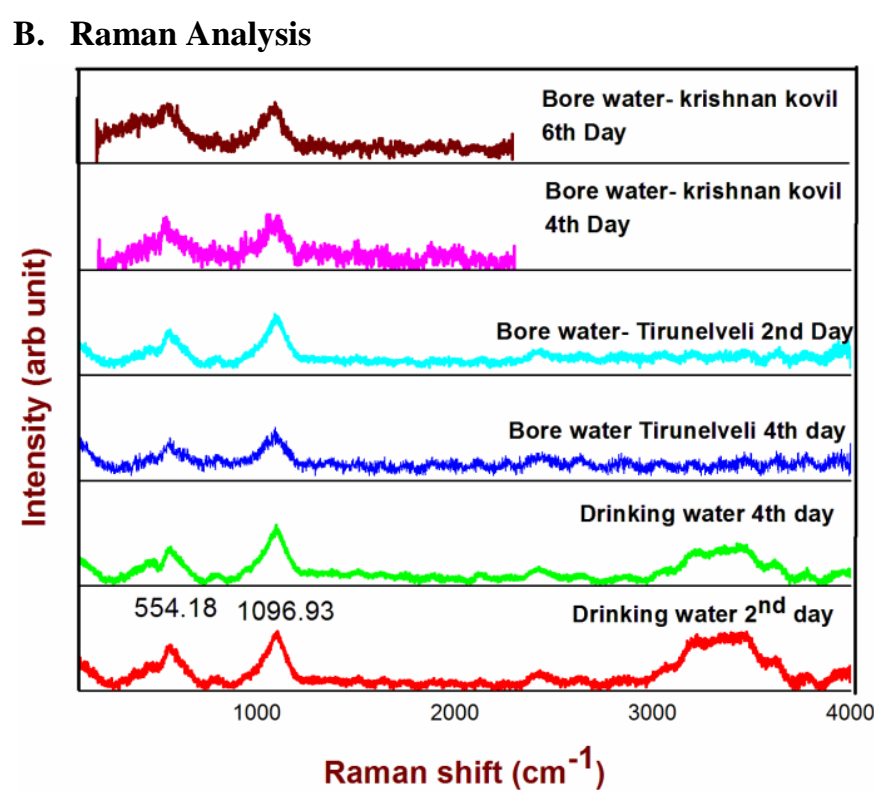

Fig.5. Raman spectral analysis of drinking water, Bore water Tirunelveli and Bore water Krishnan Kovil on consecutive even days.

One of the powerful techniques for characterizing the chemical composition of water is Raman spectroscopy. This technique is particularly well-suited for measurements of liquid samples because water is a weak Raman scattered. However, limited by the lower Raman cross-section and strong fluorescence background, complex, large size and sophisticated instruments are usually required; so many commercial Raman spectrometers are limited to laboratory use. To be used for on-line water monitoring, the Raman spectrometer should be compact, easy to use, fast, and most importantly, the limit of detection (LOD) should meet a certain level, such as the maximum contamination level (MCL). Metallic nanostructures especially $\mathrm{Au}, \mathrm{Ag}, \mathrm{Pt}$ and $\mathrm{Ru}$ possess a property of localized surface plasmon resonance (LSPR) which can greatly enhances the Raman scattering cross-section of the molecules which are adsorbed or present nearer to a metallic nanostructure. The research in SERS has attracted increasing interest because of the recent demonstration of single molecule detection $[19,20]$. In the present work we have made an attempt to find out the water peaks after consecutive even days so that we could able to find out copper peaks at $8^{\text {th }}$ day. we could not able to find such a different peak even after dropping water on $\mathrm{Ag}$ Substrate (SERS) to ensure copper peaks as shownfig 5. The normal Raman and SERS spectra remains same in all the samples and further studies to be done to find out the difference in bore water and drinking water. The peak at $554 \mathrm{~cm}^{-1}$ and $1096 \mathrm{~cm}^{-1}$ may be due to the silica or glass slide however the literature survey suggests peaks at more than $3000 \mathrm{~cm}^{-1}$ can be due to impurities in water.

\section{CONCLUSION}

The obtained TDS and $\mathrm{pH}$ are suitable for drinking purposes and well matches with WHO reports. Drinking water kept in copper vessel for 15 days shows a good change in bore well water Tirunelveli, as the TDS and $\mathrm{pH}$ decreases continuously. In the case of bore well water Krishnan kovil, TDS remains constant up to 12 days and shows sudden decrease value of 944 ppm after 2 weeks. 
The university drinking water from the beginning of analysis maintained $\mathrm{pH}$ value of 7.4 and TDS of $35 \mathrm{ppm}$ and doesn't show any variation throughout the week. In second week the TDS drastically increases and it reached $100 \mathrm{ppm}$. Overall results concluded that copper can be used effectively for drinking storage purpose up to 3 weeks and maintains $\mathrm{pH}$ and TDS without any bacterial growth. The colour change in copper vessel for bore water shows the leaching of hard minerals into copper after 2 weeks and could be the main reason of decrease in TDS. Uv-Vis and Raman studies are in investigation. Copper vessels can be used for drinking purposes as conventional resources especially in rural areas when the facilities for purifier not available. We have finally concluded that no copper has been leached out into water from copper vessel.

\section{ACKNOWLEDGMENT}

All authors want to thank Kalasalingam Academy of Research and Education for providing characterization facilities at International Research Centre (IRC) and Indian institute of science (CenSe MNFC for Raman studies). On behalf of all authors, the corresponding author states that there is no conflict of interest.

\section{REFERENCES}

[1] Bureau of Indian Standards (BIS) "Guidelines for drinking water quality standards". CCME, BIS: 10500. 2012.

[2] Shu, W. Pay attention to the human health risk of drinking low mineral water. Štambuk-Giljanović, N., 1999. Water quality evaluation by index in Dalmatia. Water Res.33 ed. vol. 16, 2015, pp. 3423-3440.

[3]V.B.Preethisudha,S.Ganesan,G.P.Pazhani,T.Ramamurthy, G.B.Nair and P.Venkatasubramanian 'Storing Drinking-water in Copper pots Kills Contaminating Diarrhoeagenic Bacteria", March 2012 Journal of Health Population and Nutrition 30(1): pp.17-21.

[4] S.Sarsan,"Effect of storage of water in different metal vessels on coliforms" ISSN: 2319-7706 vol. 2 Number 11, 2013, pp. 24-29.

[5] M.S.S.Abujazara, S.Fatihah, A.E.Kabeel, S.Sharil and S.S.Abuamr "Evaluation quality of desalinated water derived from inclined copper-stepped solar still" vol. 131, 2018, pp.83-95

[6] C.E.Santo, E.W.Lam, C.G.Elowsky, D.Quaranta, D.W.Domaille, C.J.Jhang and G. Grass, "Bacterial killing by dry metallic copper surfaces" Applied and Environmental Microbiology, vol. 77(3), 2011, pp. 794-802,

[8] J.O.Gorman and H.Humphreys,"Application of copper to prevent and control infection. Where are we now", Journal of Hospital Infection, vol. 81(4), (2012) pp. 217-223

[9] D.R.Thomas, B.Sunil, C.Latha and B.Chacko,"Microbiological Quality of Water Stored in Copper,Earthenware and Stainless Steel Vessels",Citation: IJAEBpp. vol. 7(1), March 2014,pp. 25-28

[10] N.Mohanan,E.K. Manju and S.Jacob,"The Effect of Different Types of StorageVessels on Water Quality", vol. 6, Issue 10, October 2017

[11] R.Shrestha, D.R. Joshi, J.Gopali and Sujan Piya,"Oligodynamic Action of Silver, Copper and Brass on Enteric Bacteria Isolated from water of Kathmandu Valleym Water" Nepal Journal of Science and Technology vol. 10,2009, pp. 189-193.

[12] R.Islam , S.Md. Faysal, Md. R. Amin , F.M.Juliana et al., “Assessment of $\mathrm{pH}$ and Total Dissolved Substances (TDS) in the Commercially Available Bottled Drinking Water"IOSR Journal of Nursing and Health Science (IOSR-JNHS) e-ISSN: 2320-1959.p- ISSN: 2320-1940 Volume 6, Issue 5 Oct .2017, PP 35-40

[13] World Health Organization. 1996. Total dissolved solids in Drinking-water: Background document for development of WHO Guidelines for Drinking-water Quality.

[14] Bruvold WH, Ongerth HJ. Taste quality of mineralized water. Journal of the American Water Works Association, 1969, 61:170.

[15] McClanahan MA, Mancy KH. Effect of pH on the quality of calcium carbonate film deposited from moderately hard and hard water. Journal of the American Water Works Association, 1974, vol. 66(1) pp.49-54

[16]. Langelier WF. Chemical equilibria in water treatment. Journal of the American Water Works Association, vol. 38(2),1946, pp.169-178.

[17] S.Moniri1, M.Ghoranneviss1, M.Reza Hantehzadeh1,M. Asadi Asadabad "Synthesis and optical characterization of copper nanoparticles prepared by laser ablation”Bull. Mater. Sci., vol. 40, No. 1, February 2017, pp. 37-43
[18] Gowen, A.; Tsenkova, R.; Bruen, M.; O'donnell, C. Vibrational spectroscopy for analysis of water for human use and in aquatic ecosystems. Crit. Rev. Environ. Sci. Technol. vol. 42, 2012, pp. 2546-2573.

[19] Hasan, J.; Goldbloom-Helzner, D.; Ichida, A.; Rouse T.; Gibson, M. "Technologies andTechniques for Early Warning Systems to Monitor and Evaluate Drinking Water Quality: A State-of-the-Art Review;" EPA/600/R-05/156; U.S. Environmental Protection Agency:Washington, DC, USA, 2005

[20] Z. Li, M.J. Deen , Shiva Kumar and P. R. SelvaganapathyRaman Spectroscopy for In-Line Water Quality Monitoring Instrumentation and PotentialSensors 2014, vol. 14, pp.17275-17303

\section{AUTHORS PROFILE}

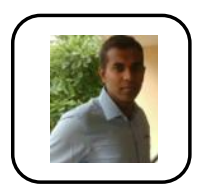

Dr Naidu Dhanpal Jayram is working as assistant professor department of physics kalasalingam Academy of Research and Education. His Research interests are thin films and nanomaterials. His specific area of research is development of substrates for Surface Enhanced Raman Spectroscopy. He has obtained his doctorate degree from Bharathiar University, Coimbatore, Tamilnadu. He is recipient of National Postdoctoral fellowship and completed Postdoc from Indian institute of science, Bangalore. He is published 12 papers in international and national journals.

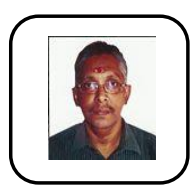

K. Viswanathan has completed M.Sc. and Ph.D. from University of Kerala Trivandrum in 1984 and worked in the High Energy Cosmic Ray group of TIFR for 22 years. Worked as Professor and HoD of Physics in Karpagam University for 10 years.Joined Kalasalingam University in August 2016 as Senior Professor. His fields of interest are molecular spectroscopy and Astroparticle physics at high energies

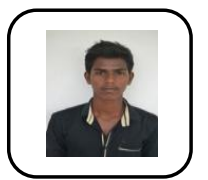

Vinoth Kumar has completed his under graduation from department of Physics, Kalasalingam Academy of research and education. He is currently as sales executive in Bajaj finserv.

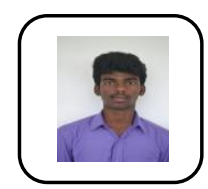

Mugeshkumar S has completed his under graduation from department of Physics, Kalasalingam Academy of research and education. He is currently working in share market forex trading.

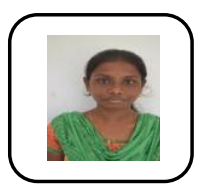

Vanitha $\mathbf{V}$ has completed his under graduation from department of Physics, Kalasalingam Academy of research and education. Currently she is pursing B.Ed., Special Education from kalasalingam Academy of Researcch and Education. 